\title{
VISION-BASED DAMAGE DETECTION OF AIRCRAFT ENGINE'S COMPRESSOR BLADES
}

\author{
Krzysztof HOLAK ${ }^{1}$, Wojciech OBROCKI ${ }^{2}$ \\ ${ }^{1}$ AGH University of Science and Technology, holak@agh.edu.pl \\ ${ }^{2}$ Rzeszow University of Technology, wojciech.obrocki@gmail.com
}

\begin{abstract}
In this paper, a new vision-based method for an evaluation of aircraft engine's compressor turbine blade damage is presented. The algorithm developed in the research uses image processing and analysis techniques for detection, localization and evaluation of the extent of compressor blades' damage. An introduction of local pixel intensity standard deviation image (SDI) computed for each image pixel made it possible to perform a correct image binarization and damage detection even for images taken in poor lighting conditions and corrupted by specular reflections, shadows and micro reflections from blade's surface roughness. Fractal dimension (FD) analysis of the blade's edge has been applied for automatic localization of detected damage along the blade's edge. An extraction of damage for computation of its geometrical dimensions was carried out with a help of binary image convex hull complement. The performance and accuracy of the developed method was compared with other image analysis methods. Hough transform for marker detection has been used as a method for scaling. The application of the developed measurement tool may be a useful aid in diagnostic inspections of aircraft engines using endoscopic cameras.
\end{abstract}

Keywords: aircraft engine, compressor blade diagnostics, image processing, vision-based damage detection

WIZYJNA DETEKCJA USZKODZEŃ ŁOPATEK SPRĘŻARKI SILNIKA LOTNICZEGO

Streszczenie

W artykule przedstawiono nową, wizyjną metodę oceny uszkodzeń łopatek turbiny sprężarki silnika lotniczego. Algorytm opracowany $\mathrm{w}$ badaniach wykorzystuje techniki przetwarzania i analizy obrazu do wykrywania, lokalizacji i oceny stopnia uszkodzenia łopatek. Wprowadzenie obrazu lokalnego odchylenia standardowego intensywności pikseli (SDI) o wartościach obliczonych dla każdego piksela obrazu wejściowego umożliwiło poprawną binaryzację obrazu i wykrycie uszkodzeń nawet w przypadku zdjęć wykonanych $\mathrm{w}$ złych warunkach oświetleniowych i zaburzonych przez refleksy świetlne, cienie i mikroodbicia od chropowatej powierzchni łopatki. Analiza wymiaru fraktalnego (FD) krawędzi łopatki sprężarki została zastosowana w celu automatycznej lokalizacji uszkodzeń na krawędzi łopatki. Wyodrębnienie uszkodzenia z obrazu do obliczenia jego wymiarów geometrycznych przeprowadzono za pomocą dopełnienia binarnego obrazu do powłoki wypukłej. Skuteczność i dokładność opracowanej metody porównano $\mathrm{z}$ innymi metodami analizy obrazu. Do wykrywania markerów skalujących zastosowano transformatę Hougha. Wprowadzenie opracowanego narzędzia pomiarowego może okazać się pomocne w badaniach diagnostycznych silników lotniczych z wykorzystaniem kamer endoskopowych.

Słowa kluczowe: silnik lotniczy, diagnostyka łopatek sprężarki, przetwarzanie obrazów, wizyjna detekcja uszkodzeń

\section{INTRODUCTION}

Aircraft turbine engine compressors pump air into the engine internal ducts. At the same time, a negative air pressure is created upstream of the compressor inlet. Hence, this negative pressure can lead to the suction of a foreign body into the compressor and cause its damage called Foreign Object Damage (FOD) [1]. The rotational speed of the aircraft turbine engine's rotor ranges from 20,000 to $60,000 \mathrm{rpm}$. Therefore, even a small foreign body sucked inside the engine often causes great damage to its gas tract and can be the direct cause of the aircraft crash. Large diameter of rotating elements in successive stages of the compressor and their large speed of rotation also causes that air is not only drawn directly from the front of the inlet, but also from its entire vicinity. The air stream flowing into the compressor is disturbed and vortices are formed [2].

It was established that the role of the factor related to the suction of foreign bodies is a significant problem for both military aviation as well civil air transport. Despite taken actions, there are still many cases of FOD. The greatest danger of a foreign body being sucked in is during take-off and landing. Currently, about $50 \%$ of engine failures occur on runways.

Additionally, the engine compressor blades operate in complex stress conditions caused by a 
continuous change of engine operating parameters [3]. It was established that the cracking of the blades is most often caused by the action of bending forces. It was found in experimental tests of the blades [4-7] that the main causes of compressor blades cracks development are variable bending loads. The analysis of damaged blades shows that blades' collision with a foreign body leads to creation of a notch causing the stress concentration and reducing the fatigue strength of the blade material [8].

Aero engine compressors are periodically inspected to maintain their proper performance. The most common tests are visual examinations with the use of special optical instruments [9-10]. To identify the damage and evaluate its extent, its width and length, as well as its location on the surface of the blade is measured. Visual examinations make it possible to characterize the mechanical damage and the effects of corrosion, overheating, scorching and erosion of the compressor blades without a need for disassembly. These periodic inspections are carried out through the inspection openings (through the compressor inlet and the exhaust gas outlet) using three basic devices: borescope, fiberscope and videoscope (endoscope). The transmission of the light beam to the specimen near the borescope lens is realized from an external illuminator through a separate optical fiber. Source of the light is a halogen or xenon bulb. The development of optical fiber technology made it possible to construct a flexible fiberoscope. The optical fiber transmits an optical image of the tested object to the observer. The signal source is a micro camera located in the measuring head.

An application of inspection significantly reduces the risks caused by compressor blades' damage during the engine operation. However, the internal structure of the aircraft engine makes the visual diagnostics often hard to perform. Miniature cameras of endoscopes record images under artificial light and from a close distance to the inspected part, ranging from a few $\mathrm{mm}$ to a few $\mathrm{cm}$. Therefore, often in the captured images, there are image artifacts present, such as specular reflections causing overexposure and shadows. This phenomena make the visual analysis of the damage difficult and may lead to large errors. What's more, damage is detected and evaluated manually by human operators, which cause a great discrepancy of obtained results.

The analysis of data from the periodic inspections of engines shows that it is possible to objectify the results of endoscopic examinations. This requires development of procedures for automatic or semi-automatic processing of imaged damaged blades. A development of information technology, increasing computing power and the advance of modern image analysis algorithms make the vision-based method an interesting alternative to the manual visual inspection in the field of the engine's compressor blades diagnostics. The task of each vision system is to obtain information contained in the image, analysis of the collected data and undertaking specific tasks on its basis. An input signal to the vision system are single images or image sequences in the form of a video signal. On the other hand, the output signal is a transformed image or numerical data about the image or its selected objects.

In the literature, there are many applications of vision-based systems for nondestructive evaluation and structural health monitoring. For example, in [11] there is presented a use of the computer vision to measure the static deformation profile of the beam structure and detect damage. Rucka et al. presented a method of crack localization in beamlike structures based and wavelet transformation and extended the use of the method to plates $[12,13]$. The vision system for deflection measurement of civil engineering structures employing digital image correlation (DIC) method was presented in [14]. The developed solution was also tested on a tram viaduct under operating conditions in [15]. In [16], an image-based method for bridge deformation measurement that considers camera motion was presented.

The analysis of the current state of the art in the area of image analysis shows that it is justified to use of a vision system for detection, classification and measurement of damage geometry of aircraft engine compressors' blades. Image processing methods may provide a tool supporting the work of condition monitoring specialists.

In this paper, a vision-based method of an analysis of aircraft engine's compressor turbine blades' damage is shown. Authors introduced local pixel intensity standard deviation image (SDI) to carry out a damage detection and evaluation even for the images taken in non-optimal lighting conditions, corrupted by specular reflections and shadows. Additionally, fractal dimension (FD) analysis of the blade's edge curvature signal was applied to automatically localize damage. Computation of damage geometrical dimensions was performed automatically with an use of convex hull complement of damage binary image. The developed method was tested on a set of compressor blade images with different types of damage introduced.

\section{DEVELOPED VISION-BASED METHOD}

In the preliminary work, authors assumed that the brightness values of pixels belonging to the blade area differ from the brightness of the background pixels. Therefore, it is decided to use binarization based on pixel brightness values for image segmentation. To have a threshold value calculated automatically, Otsu binarization method was introduced $[17,18]$. This method is applicable to images with histograms close to bimodal (i.e. having two maxima), in which object and 
background pixels have different brightness levels and the pixel count of objects and backgrounds are similar. The computed threshold maximizes the inter-class variance of pixels assigned to two classes (background and objects). In the case of a bimodal histogram, as a threshold value, the method finds pixel brightness value located in the histogram between its two extrema.

After this operation noise filtering is carried out by the means of morphological operations [18, 19]. The next step of the algorithm is to compute the geometric parameters of the blade's damage. The shape of damaged blade in the binary image is concave because of a notch presence. To identify damage the following process is carried out: the binary image of the damaged blade is completed to its convex shell, then the original binary image of the damaged blade is subtracted from the resulting image. The result of this process is an image with an object corresponding to damage. In the final step, geometrical parameters of damage are computed and its extent is evaluated. To find the location of damage on the blade surface, edge filter is used. It is assumed that the edge of an undamaged blade is approximately a straight line in the image. Every disturbance of the course of this line indicates the occurrence of damage. Therefore, the damage location along the edge of the blade is determined based on the edge's second derivative signal. The last step of the developed algorithm is finding the scale coefficient to obtain damage dimensions in metric units. Special calibration marker in a form of a small chessboard is placed on the blade's surface. Detection of the marker and computation of the scale is performed automatically with the help of Hough transform. First, lines passing through two perpendicular sides of the chessboard square are found and then the corners positions are computed as a points of these lines intersections.

The presented method works correctly only in the laboratory conditions when there is a possibility of obtaining images with big contrast between a blade and its background. However, in practice, there are often lightning artifacts present such as specular reflections and shadows. Moreover, the texture of a blade is nonuniform in brightness value because of light micro reflecting from its rough surface. In such cases, the use of automatic binarization, such as the Otsu method, leads to segmentation errors. Also, damage localization algorithm does not work in practice, because applied second derivative method is susceptible to any noise present in the signal.

Authors of the paper introduced two modifications of the image processing technique which help to deal with the aforementioned drawbacks. To simplify the binarization process, additional preprocessing in the form of standard deviation image (SDI) filtering was introduced. To localize the damage along the blade's edge robustly, fractal dimension analysis was introduced.
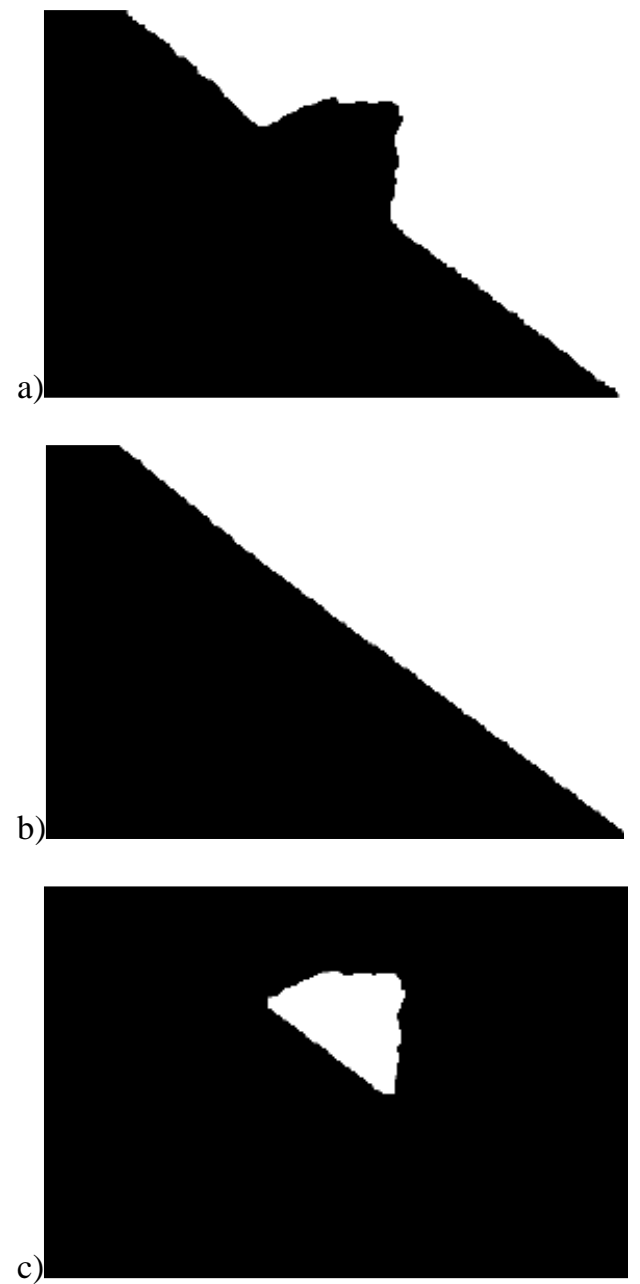

Fig. 1. The damage detection process in the binary image of the aircraft engine's compressor blade, a) the close-up of input binary image with blade segmented out as an object, b) convex hull of the blade's binary image, c) the result of binary image operation. The geometrical shape of damage has been isolated from the rest of the image.

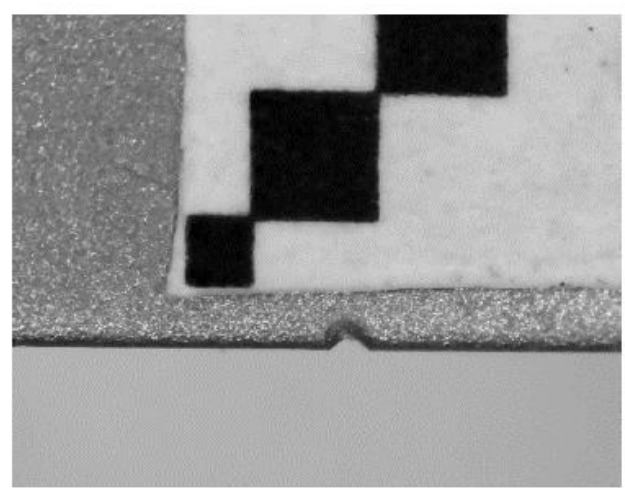

Fig. 2. Close-up of the damage present on the blade's surface. Marker for scale coefficient computation is seen. The corner points of the chessboard squares are found by Hough transform and line intersection computation. 


\subsection{Standard deviation image filtering}

An important reason of the compressor blade's image segmentation failure is a presence of a rich texture on its surface. It is characterized by a large variation in pixel brightness levels. The solution to the problem is a modification of the brightness distribution levels to one that is more uniform in the areas of the blade and its background. The local pixel level standard deviation image filtering has been introduced as a preprocessing step. The image is filtered using a local standard deviation filter that assigns to each pixel a new value which is computed based on the standard deviation of pixels in its specified neighborhood. For each pixel of the image, the standard deviation is computed using a formula

$$
\sigma=\sqrt{\frac{\sum_{\mathrm{i}=1}^{\mathrm{M}} \sum_{\mathrm{j}=1}^{\mathrm{N}}\left(\mathrm{x}_{\mathrm{i}, \mathrm{j}}-\overline{\mathrm{x}}\right)}{\mathrm{MN}}}
$$

where: M,N - size of the neighborhood (number of pixels) in horizontal and vertical directions, $\mathrm{x}_{\mathrm{i}, \mathrm{j}}$ intensity of a pixel with indices $\mathrm{i}, \mathrm{j}, \mathrm{x}$ - mean intensity of pixels in the neighborhood of $x_{i, j}$ computed using the equation

$$
\bar{x}=\frac{\sum_{i=1}^{M} \sum_{j=1}^{N} x_{i, j}}{M N}
$$

In the image after SDI filtering, low values of standard deviation correspond to black pixels (value close 0 ) and high values correspond to white pixels (value close to 255). Therefore, image regions of uniform intensity become dark and areas of high pixel variation become bright. Specular reflections and shadows, which are characterized by low pixel intensity variation are changed to dark regions. The blade surface becomes white, due to large variations of its pixels. Next, an image filtered by local SDI filter can be segmented using standard binarization method. An example of an image obtained using proposed methods is shown in fig. 3 .

Figure 4. presents an application of the proposed method for damage detection in the image with adverse lighting conditions. The presence of shadow makes it hard to use standard image processing algorithms.

\subsection{Fractal dimension processing for damage localization}

Another improvement of the image-based damage detection and evaluation method is an automatization of damage localization based on the edge curvature analysis. The first step is the blade's edge detection performed in the SDI image.

In the proposed approach, the signal's second derivative was replaced by Katz fractal dimension [20] computed at each point of the curve. The fractal dimension [21] describes the measure of the complexity of a shape, e.g. degree of its branching. It is also defined as a measure of how much a space is filled with an object - the element in which it is embedded. The fractal dimension, unlike the dimension in the classical geometry, can also take non-integer, or even irrational values. For regular objects known from classical geometry: lines, circles, or spheres, this dimension equals $n$, where $n$ is the number of dimensions of the space in which the object is placed. In the case of fractal objects, their dimension is always smaller than the dimension of the space in which they are located.

a)

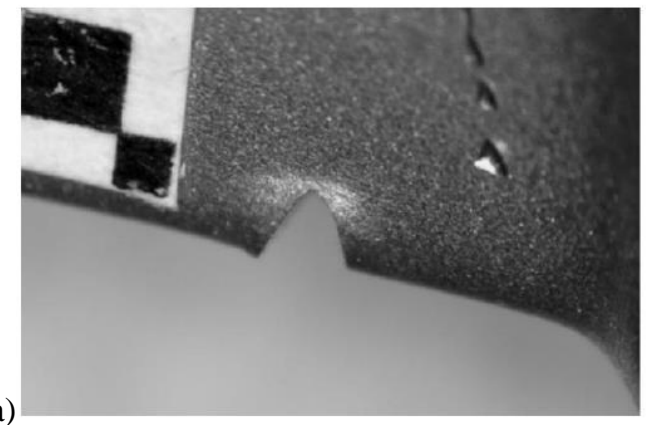

b)

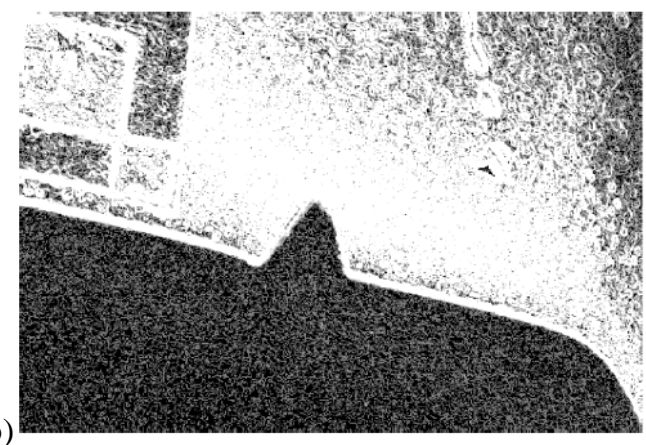

c)

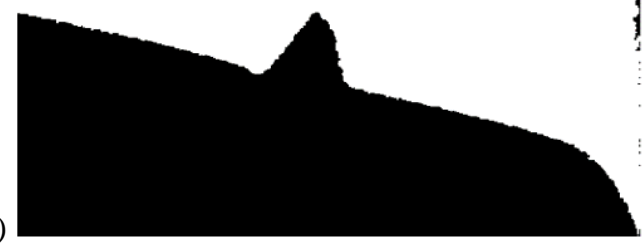

Fig. 3. An application of local pixel intensity standard deviation image filtering, a) the input image - specular light reflection, shadowing and texture due to micro reflections on blade's surface roughness can be seen, b) image processed by pixel level SDI filtering -contrasting brightness of blade with respect to background can be noticed, c) results of binarization of SDI and morphological filtering.
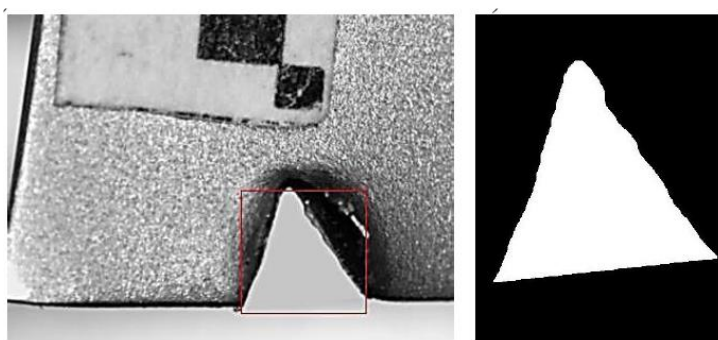
Fig. 4. An example of damage with adverse lighting conditions. The presence of dark shadows and bright blade's surface. Small specular reflections are also visible.

The method improved the robustness of damage localization significantly. In the method, a size of a neighborhood $\mathrm{S}$ is defined and Katz fractal dimension is computed at each point using a formula

$$
K F D=\frac{\log (n)}{\log (n)+\log \left(\frac{d}{L}\right)}
$$

in which: $\mathrm{n}$ - number of line segments of the curve inside a neighborhood $\mathrm{S}$, the number depending on the number of curve points, L - a total length of the curve inside the neighborhood $\mathrm{S}$, which is a sum of Euclidean distances between pairs of each two consecutive points of the curve $\left(l_{i, i+1}\right)$ given by the formula

$$
L=\sum_{i=1}^{S-1} l_{i, i+1}
$$

and $\mathrm{d}$ is a distance between first curve point inside a neighborhood $\mathrm{S}$ and a point which is at the maximum distance from it given by relation

$$
d=\max \left\{l_{1, j}\right\}
$$

Katz fractal dimension is equal to 1 for a straight line segment and has values larger than one when a curve deviates from a line. Therefore, this quantity is used to localize damage as a point on the blade's edge at which the deviation from a straight line is the largest. Example of the application of the method is shown in figure 5 .

\section{EXPERIMENTAL VERIFICATION OF THE METHOD}

The developed damage detection, localization and evaluation method was verified experimentally on a set of 16 damaged compressor's turbine blades (Figure 6a) of the TWD-10B/PZL-10S aircraft engine that propels the aircraft AN-28. Damage was introduced to the blades' surface in a form of a triangular notch. The referential geometric dimensions of the damage were measured manually using a digital microscope Dino-Lite Edge AM7515MZT which provides image resolution of $2592 \times 1944$ pixels and magnification values between 20x and 220x (Figure 7). The location of damage was constant in the experiment. Width of the notch ranged from 0,2 to $0,55 \mathrm{~mm}$, and its corresponding depth ranged from $0,04 \mathrm{~mm}$ to 0,33 $\mathrm{mm}$. Notch damage geometrical parameters are given in a table 1 , in which $\mathrm{h} 1$ - a distance measured from the base of a blade to the damage, $x$ - width of damage, and y - depth of damage (also see Fig. 5c). Images of blades for processing using the developed method were captured by Nikon D5100 digital camera with 16.2 MPix sensor.
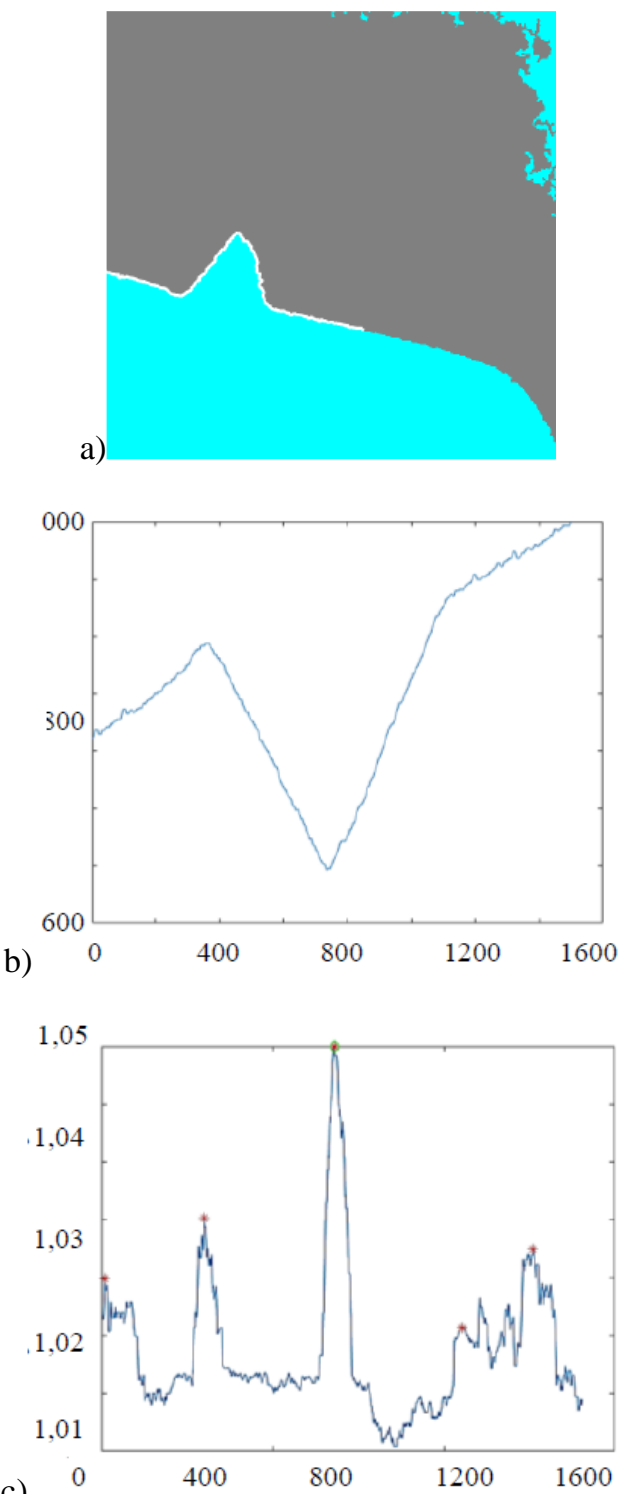

Fig. 5. An application of Fractal dimension method for damage localization, a) binary image of the blade with blade's edge detected, b) representation of the blade's edge curve, numbers on the axes correspond to indices of pixels of the detected edge, $c$ ) the result of the Fractal dimension computation on the edge signal - the $\mathrm{x}$-axis corresponds to the number of edge pixel along horizontal dimension of the image, the $y$-axis corresponds to the value of Fractal dimension.

As a measure of a performance of the proposed vision-based method, a relative error between the referential values of geometric damage parameters and the ones obtained using the proposed method was computed. It was given by the formula

$$
\delta_{x}=\frac{\left|x-\mathrm{x}_{0}\right|}{\left|\mathrm{x}_{0}\right|} * 100 \%
$$

where : $\mathrm{x}$ - the value of geometric parameters measured using vision-based methods and $\mathrm{x}_{0}-$ the true value of the parameter measured manually using laboratory microscopic setup. 
The developed method was compared with simpler image processing techniques. The results has been presented in table 2 in which the following notation was used 1) method 1 - simple binarization with one threshold, 2) method $2-2$ thresholds binarization and computation of local $\mathrm{min} / \mathrm{max}$ of grey levels to reduce an impact of the specular reflection, 3) method 3 - segmentation of intensity level standard deviation image, 4) method 4 - segmentation of local pixel intensity SDI with automatic localization of damage based on the second derivative of the blade's edge signal, 5) method 5-developed method segmentation of local pixel intensity SDI with an automatic localization of damage based on Katz fractal dimension analysis.

a)
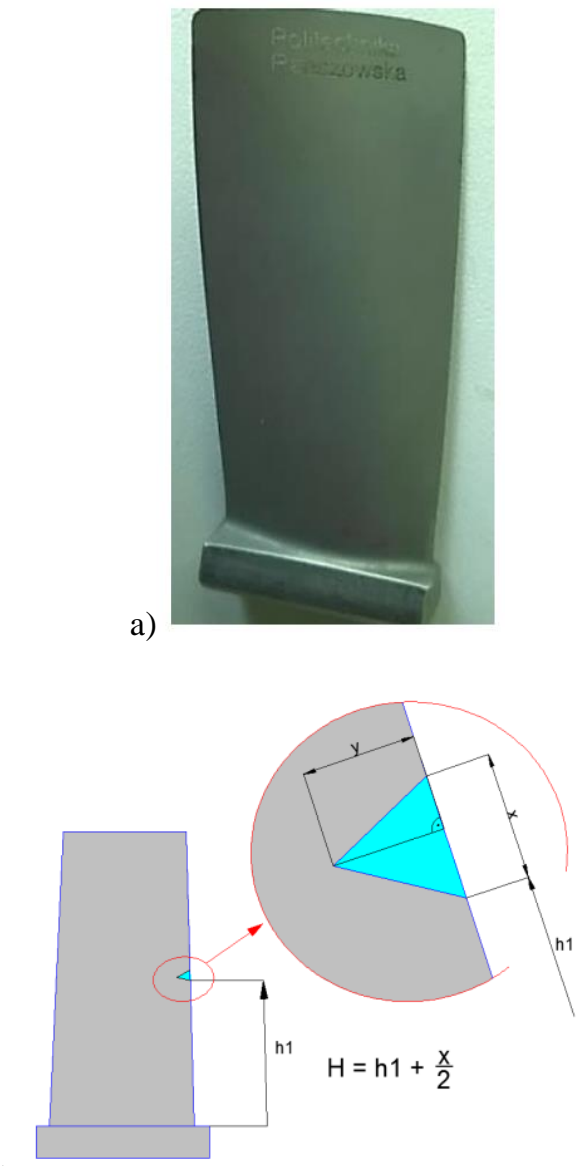

b)

Fig. 6. Research material investigated in laboratory experiments, a) an example of the blade of the first stage of TWD-10B/PZL-10S aircraft engine compressor, b) schematic drawing showing the geometric parameters of notch damage measured in the experimental investigation.

The performed experiment revealed that the developed vision-based method obtained the best results compared to other applied techniques. The first method did not work in most cases and did not correctly evaluate damage in 8 of 16 samples. The method 4 which automatically localize the presence of damage based on second derivative did not compute the correct position of damage for 5 smallest cases of the introduced notch. The shown mean localization error of this method is computed based only on the correctly localized damage cases. It turned out, the proposed method was characterized by the smallest error. It amounted, in the case of notch depth measurement, to 8,25\% and, in the case of width measurement, it reached the value of $12,13 \%$. The mean relative error of damage position localization was equal to $0,92 \%$.

Table 1. Referential geometric parameters of the introduced notch measured using a microscope. Notch damage geometrical parameters: $\mathrm{h} 1$ - a distance measured from the base of a blade to the notch damage, $x$ - width of damage, and y - depth of damage.

\begin{tabular}{|crrrrr|}
\hline Sample & \multicolumn{5}{c|}{$\begin{array}{c}\text { Geometric parameters of a notch measured } \\
\text { using a microscope }\end{array}$} \\
\hline No & h1 [mm] & $\mathbf{x}$ [mm] & $\mathbf{y}[\mathbf{m m}]$ & $\mathbf{H}$ [mm] & $\begin{array}{c}\text { Area } \\
{\left[\mathbf{m m}^{2}\right]}\end{array}$ \\
\hline L0137 & 11,31 & 0,20 & 0,04 & 11,41 & 0,01 \\
L0138 & 9,53 & 0,21 & 0,08 & 9,64 & 0,01 \\
L0139 & 8,61 & 0,22 & 0,04 & 8,72 & 0,01 \\
L0140 & 9,86 & 0,24 & 0,06 & 9,98 & 0,01 \\
L0141 & 9,34 & 0,33 & 0,11 & 9,51 & 0,02 \\
L0142 & 9,51 & 0,28 & 0,11 & 9,66 & 0,01 \\
L0143 & 9,92 & 0,3 & 0,13 & 10,07 & 0,05 \\
L0144 & 9,57 & 0,34 & 0,10 & 9,75 & 0,02 \\
L0145 & 11,61 & 0,54 & 0,29 & 11,88 & 0,09 \\
L0146 & 9,60 & 0,51 & 0,28 & 9,86 & 0,09 \\
L0147 & 10,92 & 0,41 & 0,20 & 11,13 & 0,05 \\
L0148 & 9,71 & 0,48 & 0,24 & 9,95 & 0,06 \\
L0149 & 11,04 & 0,5 & 0,31 & 11,3 & 0,10 \\
L0150 & 10,13 & 0,54 & 0,30 & 10,40 & 0,11 \\
L0151 & 10,45 & 0,57 & 0,32 & 10,7 & 0,11 \\
L0152 & 10,01 & 0,55 & 0,33 & 10,29 & 0,12 \\
\hline
\end{tabular}

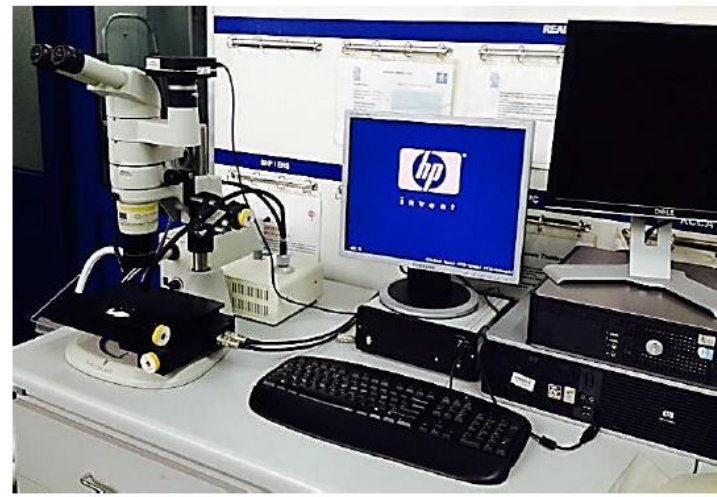

Fig. 7. Lab stand for measurement of the damage width and depth damage at the edge of the blades.

\section{CONCLUSIONS}

In the paper, a new vision-based measurement method for an evaluation of aircraft engine's compressor turbine blades damage has been presented. The method introduces local pixel intensity standard deviation image to carry out correct damage segmentation even for the cases of images corrupted by presence of shadows and specular reflections. Fractal dimension analysis of 
Table 2. Relative error of vision based measurement methods' results and a reference values obtained using the microscope. Geometric parameters: hl - a distance measured from the base of a blade to the notch damage, $x$

- width of damage, and y - depth of damage. The description of used method in the text.

\begin{tabular}{|c|c|c|}
\hline Method No & Parameter & Error [\%] \\
\hline \multirow{3}{*}{$\begin{array}{c}\text { Single-threshold } \\
\text { binarization }\end{array}$} & h1 & - \\
\hline & $\mathrm{x}$ & 25,20 \\
\hline & $\mathrm{y}$ & 20,14 \\
\hline \multirow{3}{*}{$\begin{array}{l}\text { 2-thresholds } \\
\text { binarization }\end{array}$} & h1 & - \\
\hline & $\mathrm{x}$ & 18,43 \\
\hline & y & 10,90 \\
\hline \multirow{3}{*}{$\begin{array}{l}\text { SDI image } \\
\text { binarization }\end{array}$} & h1 & - \\
\hline & $\mathrm{x}$ & 21,42 \\
\hline & $\mathrm{y}$ & 15,99 \\
\hline \multirow{3}{*}{$\begin{array}{c}\text { SDI image } \\
\text { binarization/ 2nd } \\
\text { second derivative }\end{array}$} & h1 & 0,927 \\
\hline & $\mathrm{x}$ & 13,91 \\
\hline & $\mathrm{y}$ & 12,17 \\
\hline \multirow{3}{*}{$\begin{array}{c}\text { SDI image } \\
\text { binarization/Katz } \\
\text { fractal dimension }\end{array}$} & h1 & 0,916 \\
\hline & $\mathrm{x}$ & 12,13 \\
\hline & $\mathrm{y}$ & 8,25 \\
\hline
\end{tabular}

the blade's edge signal was used to localize damage automatically and turned out to be more robust to noise than known methods based on second derivative computation. The method has been compared with other image analysis techniques in experimental analysis

The developed vision techniques allow for the determination of the aircraft engine compressor blade's damage geometrical parameters to be found on the basis of the blade's image acquired during the technical inspection of the engine. Width and depth of damage and its position on the edge of the blade relative to the selected reference point is automatically calculated. However, in the present state of the research, only blades of the compressor's first stage were inspected. An application of the method for the inspection of inner stages is a topic of the further work. One of the most important improvement of the method will be an introduction of the better image segmentation algorithm, suitable for highly variable background and lighting conditions. Another important steps in the future research are a 3D reconstruction of the blade's shape and surface analysis, involving AI methods.

The developed measurement tool can become an aid in the state evaluation of aircraft engines using endoscopic cameras.

\section{SOURCE OF FUNDING}

Part of the research presented in the paper was supported by the National Centre for Research and Development (NCBiR) under Grant No. 039/L5/2013 (LIDER V).

\section{REFERENCES}

1. Masłyk M, Obrocki W, Setkowicz A, Sieniawski J. Experimental fatigue strength determination of damaged aircraft engine blades. Advances in Manufacturing Science and Technology. 2016;40(4):55:66. https://doi.org/10.2478/amst-2016$\underline{0022}$.

2. Jain McCreary. Runway safety: FOD, birds, and the case for automated scanning. Insight SRI LLC (USA), Washington, DC 2010.

3. Seyed Masoud Marandi, Khosrow Rahmani, Mehdi Tajdari: Foreign object damage on the leading edge of compressor blades. Transactions of FAMENA. XXXVII-2, 2013:57:66.

4. Rygiel P, Obrocki W, Sieniawski J. Numerical Vibration analysis of turbine engine Compressor blades depending on geometry and position of the damage. Advances in Manufacturing Science and Technology. 2017;41:43-56. https://doi.org/10.2478/amst-2017-0004.

5. Peters JO, Boyce BL, Chen X, McNaney JM, Hutchinson JW, Ritchie RO. On the application of the Kitigawa-Takahashi diagram to foreign-object damage and high-cycle fatigue. Enginering Fracture Mechanics. 2002;60(13):1425-1446.

https://doi.org/10.1016/S0013-7944(01)00152-7.

6. Witek L, Wierzbińska M, Poznańska A. Fracture analysis of compressor blade of a helicopter engine. Engineering Failure Analysis. 2009;16(5):1616-1622. https://doi.org/10.1016/j.engfailanal.2008.10.022

7. Witek L. Experimental crack propagation and failure analysis of the first stage compressor blade subjected to vibration. Engineering Failure Analysis. 2006;16(5):1616-1622. https://doi.org/10.1016/j.engfailanal.2008.10.022

8. Peters JO, Roder O, Boyce BL, Thompson AW, Ritchie RO. Role of foreign-object damage on thresholds for high-cycle fatigue in Ti-6Al-4V. Metallurgical and Materials Transactions. 2010;31(6):1571-1583.

9. Spang HA, Brown H. Control of jet engines. Control Engineering Practice. 1999; 7:1043-1059.

10. Vujić D. Turbojet engine maintenance systems. Scientific-Technical Review. 2003;LIII 2.

11. Jing S, Xiangjun X, Jialai W, Gong Li. Beam damage detection using computer vision technology. Nondestructive Testing and Evaluation. 2010;25:189204. https://doi.org/10.1080/10589750903242525.

12. Rucka M. Damage detection in beams using wave let transform on higher vibration modes. Journal of Theoretical and Applied Mechanics. 2011; 49(2):399417.

13. Rucka M, Wilde K. Neuro-wavelet damage detection technique in beam, plate and shell Structures with experimental validation. Journal of Theoretical and Applied Mechanics. 2010;48(3):479-504.

14. Sładek J, Ostrowska K, Kohut P, Holak K, Gąska A, Uhl T. Development of a vision based deflection measurement system and its accuracy assessment. Measurement. 2013;46(3):1237-1249. https://doi.org/10.1016/j.measurement.2012.10.021.

15. Kohut P, Holak K, Uhl T, Ortyl Ł, Owerko T, Kuras $P$, Kocierz R. Monitoring of a civil structure's state based on noncontact measurements. Structural Health Monitoring. 2013;12(5-6):411-429.

https://doi.org/10.1177/1475921713487397. 
16. Abolhasannejad V, Huang X, Namazi N. Developing an optical image-based method for bridge deformation measurement considering camera motion. Sensors. 2018;8(9):2754;

https://doi.org/10.3390/s18092754

17. Burger W, Burge MJ. Principles of digital image processing: fundamental techniques. Springer. Londyn. 2009

18. Szeliski R. Computer vision: algorithms and applications. Springer. 2010.

19. Gonzalez R, Woods R. Digital image processing. Pearson Education. 2003.

20. Hui Li, Yong Huang, Jinping Ou, Yuequan Bao. Fractal Dimension: Based damage detection method for beams with a uniform cross-section. ComputerAided Civil and Infrastructure Engineering. 2011;26(3):190-206.

21. Falconer K. Fractal geometry. 3rd Edition. Wiley. 2014.

Received 2021-05-31

Accepted 2021-08-25

Available online 2021-08-31

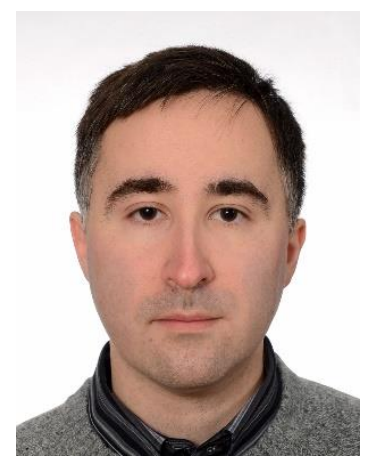

Krzysztof HOLAK, $\mathrm{PhD}$ is an assistant professor in the Department of Robotics and Mechatronics, AGH University of Science and Technology. His research is in the area of an application of vision systems and image processing methods in mechanical and civil engineering, damage detection and structural health monitoring. He works also in the field of vision system for robotics and medical image processing.

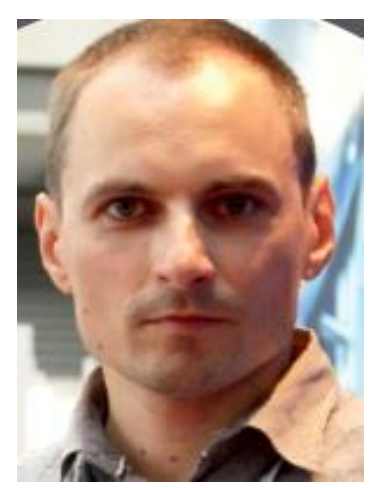

Wojciech OBROCKI, $\mathrm{PhD}$ is a researcher in the field of the aircraft engine diagnostics, inspection and maintenance. His main scientific interests are experimental fatigue analysis of the aircraft engines' compressor blades, non-destructive damage detection, localization and assessment and optical inspection of aircraft engines. 